\title{
Self-care of adolescents with type 1 diabetes: responsibility for disease management
}

\author{
Autocuidado dos adolescentes com diabetes mellitus tipo 1: responsabilidade no controlo \\ da doença \\ Autocuidado de los adolescentes con diabetes mellitus tipo 1: responsabilidad \\ en el control de la enfermedad \\ Marília Costa Flora*; Manuel Gonçalves Henriques Gameiro**
}

\begin{abstract}
Background: Type 1 diabetes (T1D) is an increasingly prevalent disease in adolescence. Intervening in self-care is essential for disease management.

Objectives: To determine the responsibility of adolescents with T1D for self-care roles, and analyze the relationship between the responsibility of adolescents with T1D for self-care roles and age and gender.

Methodology: A descriptive-analytical and cross-sectional study was conducted with a sample of 51 adolescents aged between 12 and 18 years being followed up in district hospitals of the center region of Portugal. A scale on the responsibility for self-care roles was applied. This scale consisted of 15 questions distributed by 4 dimensions: health maintenance; disease management; diagnosis, treatment and medication in T1D; and participation in health services.

Results: Most adolescents assume a high responsibility for self-care. Gender has no influence on the overall responsibility. Boys are more responsible in terms of managing insulin administration.

Conclusion: Adolescents assume personal responsibility for disease management. The sharing of responsibility with parents or others and the participation in health services are highlighted.
\end{abstract}

Keywords: adolescent; diabetes mellitus, type 1; self-care; nursing

\section{Resumo}

Enquadramento: A diabetes mellitus tipo 1 (DM1) é uma doença cada vez mais prevalente na adolescência. Intervir no autocuidado é determinante para a gestão da doença.

Objetivos: Determinar a responsabilidade dos adolescentes com DM1 nos papéis de autocuidado; analisar a relação da responsabilidade dos adolescentes com DM1 nos papéis de autocuidado com a idade e o género.

Metodologia: Estudo descritivo-analítico e transversal. Participaram 51 adolescentes entre os 12 e os 18 anos seguidos em hospitais distritais da zona centro de Portugal. Foi aplicada uma escala de responsabilidade nos papéis de autocuidado, constituída por 15 itens distribuídos por 4 dimensões: manutenção da saúde; controlo da doença; diagnóstico, tratamento e medicação na DM1; e participação em serviços de saúde.

Resultados: A maioria dos adolescentes assume responsabilidade própria elevada. O género não influencia a responsabilidade global, os rapazes evidenciam maior nível de responsabilidade na gestão de administração de insulina.

Conclusão: Os adolescentes assumem responsabilidade própria no controlo da doença, evidencia-se responsabilidade partilhada com os pais ou outros no global e na participação em serviços de saúde.

Palavras-chave: adolescente; diabetes mellitus tipo 1; autocuidado; enfermagem

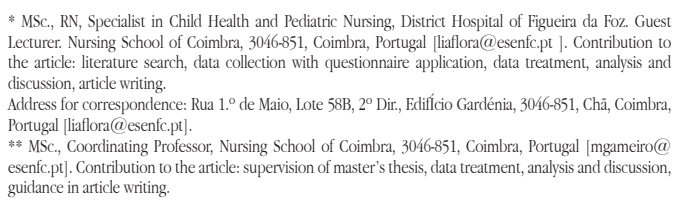

* MSc., RN, Specialist in Child Health and Pediatric Nursing, District Hospital of Figueira da Foz. Gues Lecturer. Nursing School of Coimbra, 3046-851, Coimbra, Portugal [liaflora@esenfc.pt ]. Contribution to the article: literature search, data collection with questionnaire application, data treatment, analysis and discussion, article writing.

Address for correspondence: Rua 1. ${ }^{\circ}$ de Maio, Lote 58B, $2^{\circ}$ Dir., Ediff́cio Gardénia, 3046-851, Chã, Coimbra, Portugal [liaflora@esenfc.pt].

** MSc., Coordinating Professor, Nursing School of Coimbra, 3046-851, Coimbra, Portugal Imgameiro@ esenfc.pt]. Contribution to the article: supervision of master's thesis, data treatment, analysis and discussion, guidance in article writing.

\section{Resumen}

Marco contextual: La diabetes mellitus Tipo 1 (DM1) es una enfermedad con cada vez más prevalencia en la adolescencia. Por ello, intervenir en el autocuidado es esencial para la gestión de la enfermedad.

Objetivos: Determinar la responsabilidad de los adolescentes respecto a la DM1 en el papel del autocuidado y analizar la relación de la responsabilidad de los adolescentes respecto a la DM1 en el papel del autocuidado con la edad y el género.

Metodología: Estudio descriptivo-analítico y transversal en el que participaron 51 adolescentes con edades comprendidas entre los 12 y los 18 años a los que se les realizó un seguimiento en hospitales de la zona centro de Portugal. Se aplicó una escala de responsabilidad en el papel del autocuidado constituida por 15 ítems distribuidos por cuatro dimensiones: mantenimiento de la salud; control de la enfermedad; diagnóstico, tratamiento y medicación en la DM1, y participación en los servicios de salud. Resultados: La mayoría de los adolescentes asume una responsabilidad propia elevada. El género no influye en la responsabilidad global y los niños muestran un nivel mayor de responsabilidad en la gestión de la administración de la insulina. Conclusión: Los adolescentes asumen una responsabilidad propia en el control de la enfermedad. Se observa una responsabilidad compartida con los padres y los otros a nivel global y en la participación en los servicios de salud.

Palabras clave: adolescente; diabetes mellitus tipo 1; autocuidado; enfermería

Received for publication: 07.02 .16

Accepted for publication: 30.04 .16 


\section{Introduction}

Type 1 Diabetes Mellitus (T1D) "is an autoimmune diseasecharacterized by progressive loss of pancreatic beta cells, culminating in the cessation of insulin production and, consequently, a severe metabolic imbalance" (Miculis, Mascarenhas, Boguszewski, \& Campos, 2010, p. 276). T1D is the most common endocrine disorder in childhood, with maximum incidence during early adolescence (Ross 2003, cited by Rosalind, 2006). In Portugal, the number of new cases diagnosed every year has been increasing. According to Correia et al. (2015), the incidence of diabetes in 2014 was 17.5\% (261 new cases) per 100,000 inhabitants aged 0-14 years, whereas, in 2000 , the incidence was $9.5 \%$, corresponding to 160 new cases. These results follow the international trend of increased T1D in increasingly younger age groups. T1D is associated with several complications, namely increased mortality and increased risk of micro and macrovascular complications. Diabetes is a predisposing factor for the occurrence of retinopathy, neuropathy, nephropathy, cardiovascular diseases, and diabetic foot (Santos, Silva, \& Cardoso, 2009).

In this study, we focus on the concept of adolescence as defined by the World Health Organization, which adopts the chronological criterion that covers young people aged between 10 and 19 years (World Health Organization, 2011). Due to its very specific developmental characteristics, adolescence is a period of major changes that require from the adolescents and their families a significant effort to adapt to chronic illness, as well as a differentiated intervention by the health care teams. Considering the process of transitions that adolescents go through, adolescence can be a particularly difficult time for self-care accountability, often leading to self-care deviations. In adolescents with $\mathrm{T} 1 \mathrm{D}$, the transition to autonomy is characterized as the search for independence from the parents and for autonomous decision-making (Karlsson, Arman, \& Wikblad, 2008). Diabetes demands a reorganization of the personal and family routines at several levels, implying not a cure, but rather a daily management (Ribeiro, 1998). Therefore, we believe that there is an urgent need for a more interventive action among adolescents, which represents a challenge for health care services, particularly nurses. A sustained intervention by the health care teams will impact the well-being and quality of life of diabetic adolescents and their families by reducing their anxiety and debilitated emotional status (Aguiar \& Fontes, 2007). Diabetes management reduces costs related to health care, loss of income, general society expenses and loss of productivity, being also associated with missed opportunities for economic development (Correia et al., 2015).

Thus, this study aims to assess the responsibility of adolescents with T1D for self-care roles. To this end, we designed a scale of responsibility based on the model of self-care roles designed by Santos (2001), cited by Filho, Rodrigues, and Santos (2008). For the purposes of data collection, we applied the questionnaire to adolescents with T1D who attended the diabetology consultation at the District Hospital of Figueira da Foz, EPE, and the endocrinology consultation at the Hospital Center of Baixo Vouga, EPE, as well to adolescents who belonged to an association of diabetics (AD) located in the center region of the country.

An optimized treatment of T1D since the diagnosis stage allows patients to achieve a good metabolic control, preventing complications and ensuring a smooth integration into the social, academic and professional lives. As first-rate professionals, nurses can develop a privileged work among adolescents with T1D, namely by facilitating the transfer from the parents' responsibility to the autonomous performance of self-care. For this reason, it is important to analyze the reality in nursing intervention settings. Based on this problematic background, a descriptiveanalytical and cross-sectional study was conducted with a population of adolescents with T1D, with the following objectives: to determine the responsibility of adolescents with T1D for self-care roles, and analyze the relationship between the responsibility of adolescents with T1D for self-care roles and age and gender.

\section{Background}

Diabetes refers to a specific process within the adolescents' social development; the adaptation to the disease is a constant process that relies on each person's individual characteristics. The specific characteristics of adolescents - rebelliousness, experimentation and attempt to control their own destiny - are an obstacle to the management of 
disease treatment (Fialho, Dias, Nascimento, Motta, \& Pereira, 2011). Self-care involves autonomy in behaviors, and decision-making (Hanna \& Decker, 2010). Thus, according to Dashiff, McCaleb, and Cull (2006), interventions should be different depending on the stage of disease diagnosis. When the onset of diabetes occurs during childhood, the parents and health professionals' main concern should be the performance of self-care roles. In turn, when it occurs during adolescence, the intervention should focus more on the adolescents' accountability and development of a sense of autonomy.

When defining the concepts of self-management and responsibility for self-care, Kyngas and Hentinent, 1995, cited by Hanna and Decker (2010), consider that diabetes self-management is a process aimed at glucose control and execution of the treatment regimen, from a perspective of health and/or wellbeing. In turn, assuming the responsibility for selfcare is a process focused on the autonomy and a model of development for the diabetic adolescent. Self-care management and responsibility should be integrated as adolescents start assimilating the various self-care roles. Responsibility is a process common to all adolescents for the maintenance of healthy lifestyles (universal self-care); however, in adolescents with T1D, the responsibility should focus on self-care. Considering the process of transitions that adolescents go through, adolescence can be a particularly difficult time for self-care accountability, often leading to self-care deviations. In adolescents with T1D, the transition to autonomy is characterized as the search for independence from the parents and for autonomous decision-making. These situations may lead to confusion over the responsibility for self-care management (Karlsson, Arman, \& Wikblad, 2008). However, becoming autonomous does not imply moving away from the family context, rather extending the relationship network, including other people in it. In turn, autonomy corresponds to taking initiative and implies that the adolescents' behavior reflects their values. According to Garrett (2007, p.13), "autonomy refers to the fact that the person considers himself/herself as the origin of his/ her actions and behavior". Autonomy is associated with experiences of freedom and authenticity, i.e. a locus of internal causality (Ryan, Deci, \& Grolnick, 1995, cited by Garrett, 2007). However, the process of autonomy can be facilitated if, in their social and family lives, adolescents are given attention and if interest is shown in their actions, encouraging their initiative (Garrett, 2007). With regard to the autonomy in self-care roles, Chien, Larson, Nakamura, and Lin (2007) believe that this variable depends on the age of adolescents with T1D. Thus, adolescents are encouraged to monitor blood glucose at 8 to 10 years of age, to administer insulin at 10 to 12 years of age and to comply with meal plans at 12 to 14 years of age. It should be noted that the management of self-care roles involves not only therapeutic administration, but above all the adjustment of behaviors and lifestyle (Bastos, Severo, \& Lopes, 2007).

In short, the balance between independence and dependence in self-care roles is beneficial if approached in light of the Self-Care Deficit Theory (Peixoto, 1996). Self-care management does not rely on a single factor, but it is related to the adolescents' age, their interactions with others, their self-concept and their participation in outside activities (Saucier, 1984, cited by Chien et al., 2007). Responsibility and autonomy are key concepts in self-care management by adolescents with T1D. With regard to autonomy in diabetes, a structured family and social environment supports the adolescents' autonomy and self-determination, giving them the confidence and responsibility to perform the self-care roles.

\section{Research questions}

What is the relationship between the responsibility for self-care roles and diabetes management of adolescents with T1D?

Is the personal responsibility for self-care roles associated with the adolescents' age and gender?

\section{Methodology}

Before the application of the questionnaire, we requested written authorizations from the board of directors of the District Hospital of Figueira da Foz, EPE (HDFF, EPE), the board of directors of the Baixo Vouga Hospital Center, EPE (CHBV, EPE), and an association of diabetics (AD). The study began after the favorable opinion from the ethics committees of these institutions. This is a quantitative, descriptiveanalytical and cross-sectional study. According to the 
model of analysis proposed, our key variable was the responsibility for self-care roles. Our remaining variables were the adolescents' demographic characteristics of age and gender.

\section{Population and sample: type of sample}

Of the total sample, 32 adolescents (62.7\%) were recruited in the endocrinology consultation of the CHBV, EPE; 11 adolescents (21.6\%) being followed-up in hospitals of the central region were recruited during the field activities of an $\mathrm{AD}$; and eight adolescents (15.7\%) were recruited in the endocrinology consultation of the HDFF, EPE. An accidental sampling method was used, since the adolescents were being integrated into the study as they attended the consultations/AD meetings, and only when the researcher was present. The sample was selected at different moments, between September 2012 and February 2013. In relation to gender, the sample is balanced as 25 adolescents (49\%) were girls and 26 adolescents (51\%) were boys. As regards age, the mean age of the group was 15 years $(\bar{\chi}=15.18 ; S D=2.07$; $\mathrm{Md}=15)$. The selected age groups, of similar size, show a homogenous distribution. However, there is a higher prevalence of adolescents aged between $12-14$ years. The 12-14 age group is composed of 21 adolescents (41.2\%), followed by the 15-17 age group with 19 adolescents (37.3\%), and the $>17$ age group with 11 adolescents (21.6\%). All the respondents lived in the central region of Portugal.

\section{Instrument}

We designed a questionnaire including a scale of responsibility for self-care roles, based on the model of self-care roles designed by Santos (2001), cited by Filho et al. (2008). It also included a demographic, sociocultural and clinical questionnaire. According to the authors, the self-care roles for patients with T1D are divided into the following dimensions: Health Maintenance, which consists of sustaining a better quality of life through the performance of selfcare actions, effectively enabling a healthy condition; Prevention of Acute and Chronic Complications of T1D, which consists of preventing complications in order to maintain disease under control; Diagnosis, Treatment and Medication in T1D, which consists of recognizing the signs and symptoms of hyperglycemia and hypoglycemia and therapeutic adjustment; and Active Participation in Health Services, which consists of using the available health support structures.

Although the model was used as the basis for designing the scale of Responsibility for Self-Care Roles, some aspects listed in this model applied to a sample in Brazil are not totally adjustable to the Portuguese population, being necessary to adapt some items. In the dimension Prevention of Acute and Chronic Complications of T1D, instead of the item related to measurement of glycated hemoglobin (HbAlc), which is a responsibility of the health team that monitors the adolescents and not a responsibility of the adolescent or other adults, we found it necessary to include the item related to "insulin administration, since the original authors do not mention it and we felt that this topic was essential for the effective management of self-care by adolescents with T1D. Additionally, although the authors included the dimension Prevention of Acute and Chronic Complications, we believe that, from a conceptual perspective, the various aspects in this dimension are not related to disease complications, but to its management, which was why we changed the name of the original dimension to Disease Management. Nevertheless, there is a direct relationship between the non-fulfilment of those self-care roles and the increased risk of T1D complications.

After the application of the pre-test to a group of 10 diabetic adolescents, the scale was revised in the dimension of Health Maintenance and the following items were not considered: Maintain scheduled immunizations; Practice religious activities; Avoid smoking; and Avoid drinking alcohol, since the adolescents had some doubts about them during questionnaire completion. Several adolescents assumed the score does not perform as corresponding to a denial of the consumption of these substances. In the dimension of Disease Management, the aspect related to Recognizing the importance of HbAlc was not considered.

Thus, in view of the above, the applied instrument was an adapted version composed of 15 questions divided into four dimensions: Health Maintenance; Disease Management; Diagnosis, Treatment and Medication in T1D; and Participation in Health Services. In turn, each dimension was composed of several items, as shown in Table 1.

The adolescents answered by putting an $(\mathrm{X})$ in the statement that they considered to better reflect their situation, using a 4-point Likert scale (rated 
from 0 to 3): does not perform (0); responsibility of parents or other adults (1); shared responsibility (2); and responsibility of adolescents (3). Each self- care dimension scores a maximum of 3 points. The option does not perform scores zero points since it reflects an absence of responsibility.

Table 1

Scale of responsibility for self-care roles

\begin{tabular}{lll}
\hline Health Maintenance & 1) & Control weight \\
& 2) & Maintain a balanced diet \\
& 3) & Perform leisure activities on a regular basis \\
& 4) & Reduce stress \\
\hline Disease management & 1) & Practice regular physical activity \\
& 2) & Control capillary blood glucose levels \\
& 3) & Administer insulin \\
\hline Diagnosis, treatment and medication in T1D & 1) & Detect signs and symptoms of hypoglycemia \\
& 2) & Intervene in case of hypoglycemia \\
& 3) & Detect signs and symptoms of hyperglycemia \\
& 4) & Intervene in case of hyperglycemia \\
\hline Participation in health services & 5) & Adjust insulin according to capillary blood glucose levels \\
\hline
\end{tabular}

In this scale, we assessed the overall responsibility, by calculating the mean in all items. We also assessed the responsibility score for each dimension. As to content validity, the scale was analyzed and the items considered to be more relevant were analyzed by experts in the area of diabetology, namely a pediatrician, a nurse specialized in diabetology and an endocrinologist. Adjustments were made based on the experts' suggestions.

Before the application of the final version of the instrument, a pre-test was conducted in the first meeting with the adolescents with T1D. This sample was composed of 10 adolescents, aged between 10 and 17 years. At the end of the pre-test, each adolescent was asked if he/she had any doubts concerning the questions. Some adjustments were made in dubious questions, without, however, changing their content. In this phase, we realized that the adolescents aged between 10 and 12 years had some difficulties in completing the questionnaire due to their maturity and developmental level. In addition, in this age range, the responsibility for the self-care roles is mainly attributed to their parents and/or legal guardians. Therefore, we decided to apply the instrument to adolescents over 12 years of age.

\section{Reliability of the scale of responsibility for self-care roles}

The internal consistency of the dimensions and the total scale was analyzed using Cronbach's alpha coefficients and the corrected item-total correlation, as shown in Table 2 . The value obtained for the overall responsibility for self-care roles was .745 , which indicates a good internal consistency. The values were satisfactory (above .65) for each dimension, with the exception of the dimension of Health Maintenance (.52). 
Table 2

Internal consistency of the dimensions of responsibility for self-care roles $(n=51)$

\begin{tabular}{|c|c|c|c|}
\hline Dimensions & Items & $\begin{array}{l}\text { Corrected item-total } \\
\text { correlation }\end{array}$ & $\begin{array}{l}\text { Alpha of the } \\
\text { dimension if } \\
\text { item deleted }\end{array}$ \\
\hline Health Maintenance & $\begin{array}{l}\text { Control weight } \\
\text { Maintain a balanced diet } \\
\text { Perform leisure activities on a regular basis } \\
\text { Reduce stress } \\
\text { Practice regular physical activity } \\
\text { (Cronbach's alpha of } .518 \text { ) }\end{array}$ & $\begin{array}{l}.383 \\
.351 \\
.328 \\
.235\end{array}$ & $\begin{array}{l}.413 \\
.415 \\
.450 \\
.509\end{array}$ \\
\hline Control weight & - & - & - \\
\hline Disease Management & $\begin{array}{l}\text { Measure capillary blood glucose levels } \\
\text { Control capillary blood glucose levels } \\
\text { Administer insulin (Cronbach's alpha of .840) }\end{array}$ & $\begin{array}{l}.725 \\
.725\end{array}$ & - \\
\hline Administer insulin & - & - & -.--- \\
\hline $\begin{array}{l}\text { Diagnosis, Treatment and } \\
\text { Medication in T1D }\end{array}$ & $\begin{array}{l}\text { Detect signs and symptoms of hypoglycemia } \\
\text { Intervene in case of hypoglycemia } \\
\text { Detect signs and symptoms of hyperglycemia } \\
\text { Intervene in case of hyperglycemia } \\
\text { Adjust insulin according to capillary blood glucose } \\
\text { levels } \\
\text { (Cronbach' alpha of .698) }\end{array}$ & $\begin{array}{l}.611 \\
.383 \\
.718 \\
.342\end{array}$ & $\begin{array}{l}.543 \\
.695 \\
.456 \\
.714\end{array}$ \\
\hline $\begin{array}{l}\text { Adjust insulin according } \\
\text { to capillary blood glucose } \\
\text { levels } \\
\end{array}$ & - & -- & -- \\
\hline $\begin{array}{l}\text { Participation in Health } \\
\text { Services }\end{array}$ & $\begin{array}{l}\text { Access to the health care service of reference } \\
\text { Contact with the health care team of reference } \\
\text { (Cronbach's alpha of .945) }\end{array}$ & $\begin{array}{l}.900 \\
.900\end{array}$ & - \\
\hline
\end{tabular}

The items Control weight,Administer insulin, and Adjust insulin according to capillary blood glucose levels were analyzed separately, since they had very low item-total correlation (below .20), thus negatively influencing the internal consistency of their dimensions.

\section{Data collection}

The instrument was applied in specific days previously scheduled with the nursing teams of the institutions and with the person responsible for the AD. Before the application of the questionnaire, the adolescents and legal guardians were explained the nature, objective and purpose of the study, and ensured of the data anonymity. The instrument was applied after the adolescents and the legal guardians signed the informed consent. The questionnaires were completed on an individual basis and the completion took approximately 15 minutes.

\section{Results}

Adolescents were grouped by levels of responsibility, considering the following intervals: (0-1) low personal responsibility of adolescents; (12) shared responsibility; and (2-3) bigh personal responsibility of adolescents.

According to Table 3, we observed that, in general, adolescents are responsible for the self-care roles related to disease management, with most of them showing a high personal responsibility $(\mathrm{Md}=2.4)$. Most adolescents have a high personal responsibility for self-care roles. In the dimension of Participation in Health Services, the central values are lower, with $29.4 \%$ of adolescents pointing to a shared responsibility. 
Table 3

Distribution of the sample subjects according to the categories of responsibility for self-care roles and summary measures

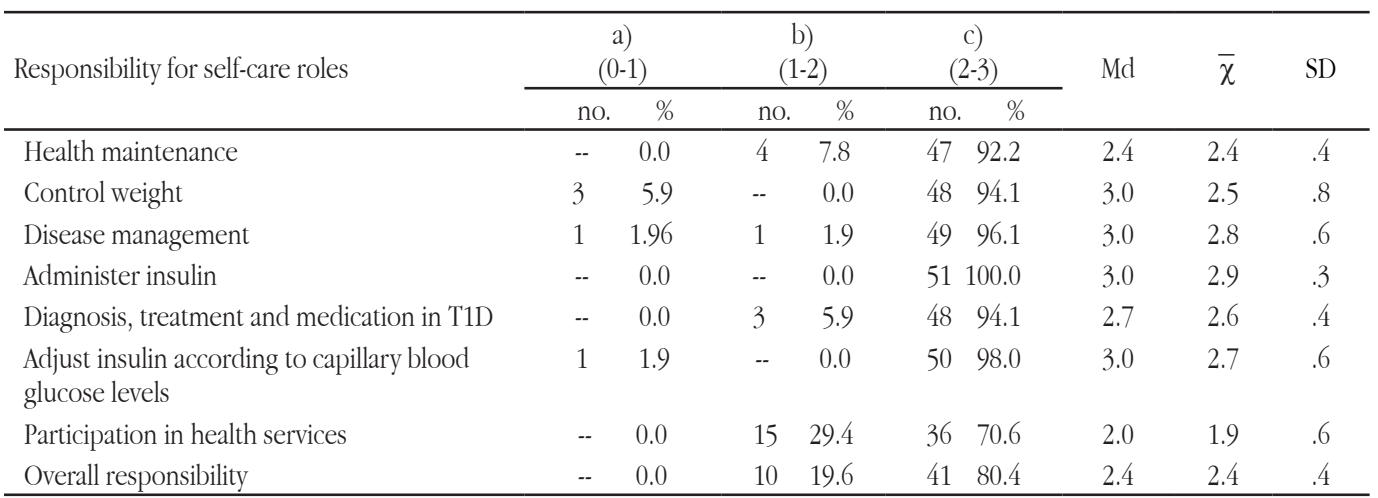

a) Low personal responsibility responsibility of adolescents.

b) Responsibility shared with parents or other adults.

c) High personal responsibility of adolescents.

Relationship between responsibility and age $\quad(r s=.406 ; \mathrm{p}=.003)$, and "Diagnosis, treatment and Table 4 shows moderate and statistically significant medication in T1D" ( $r s=.337 ; p=.016)$, and the item correlations between age and the dimensions of "Adjust insulin according to capillary blood glucose responsibility "Participation in health services" levels" $(r s=.385 ; p=.005)$.

Table 4

Responsibility for self-care roles and age $(n=51)$

\begin{tabular}{lcc}
\hline Responsibility for self-care roles & \multicolumn{2}{c}{ Age } \\
\hline \multirow{2}{*}{ Health maintenance } & $r s=$ & 0,192 \\
& $p=$ & 0,176 \\
Control weight & $r s=$ & 0,197 \\
Disease management & $p=$ & 0,167 \\
& $r s=$ & 0,230 \\
Administer insulin & $p=$ & 0,104 \\
& $r s=$ & 0,235 \\
Diagnosis, treatment and medication in T1D & $p=$ & 0,096 \\
& $r s=$ & $0,337^{*}$ \\
Adjust insulin according to capillary blood glucose levels & $p=$ & 0,016 \\
& $\mathrm{rs}=$ & $0,385^{* *}$ \\
Participation in health services & $p=$ & 0,005 \\
Overall responsibility & $\mathrm{rs}=$ & $0,406^{* *}$ \\
& $p=$ & 0,003 \\
& $\mathrm{rs}=$ & 0,195 \\
\hline
\end{tabular}

*Significance level for $\alpha<.05$; **Significance level for $\alpha<.01$.

Relationship between responsibility and gender

Gender does not seem to influence the adolescents' overall responsibility, with the exception of the item
"Adjust insulin according to capillary blood glucose levels", which showed a statistically significant difference since male adolescents show higher levels of personal responsibility (Table 5). 
Table 5

Responsibility for self-care roles and gender $(n=51)$

\begin{tabular}{|c|c|c|c|c|c|}
\hline \multirow{2}{*}{$\begin{array}{l}\text { Female } \\
(n=25)\end{array}$} & & \multicolumn{2}{|c|}{ Gender } & \multicolumn{2}{|c|}{ Mann-Whitney's U-Tes } \\
\hline & & Male $(n=26)$ & $\mathrm{Z}$ & $p$ & \\
\hline \multirow{3}{*}{ Health maintenance } & $\mathrm{Md}$ & 2.60 & 2.30 & -1.665 & .096 \\
\hline & $\bar{\chi}$ & 2.52 & 2.33 & & \\
\hline & $S D$ & .39 & .43 & & \\
\hline \multirow{3}{*}{ Control weight } & $\mathrm{M}$ & 3.00 & 3.00 & -.266 & .790 \\
\hline & $\bar{\chi}$ & 2.52 & 2.50 & & \\
\hline & $S D$ & .71 & .86 & & \\
\hline \multirow{3}{*}{ Disease management } & $\mathrm{M}$ & 3.00 & 3.00 & -.247 & .805 \\
\hline & $\bar{\chi}$ & 2.78 & 2.71 & & \\
\hline & $S D$ & .38 & .68 & & \\
\hline \multirow{3}{*}{ Administer insulin } & $\mathrm{Md}$ & 3.00 & 3,00 & -1.772 & .076 \\
\hline & $\bar{\chi}$ & 2.80 & 2.96 & & \\
\hline & $S D$ & .41 & .20 & & \\
\hline \multirow{3}{*}{$\begin{array}{l}\text { Diagnosis, treatment and medica- } \\
\text { tion in T1D }\end{array}$} & $\mathrm{Md}$ & 2.67 & 2.75 & -.730 & .466 \\
\hline & $\bar{\chi}$ & 2.57 & 2.63 & & \\
\hline & $S D$ & .42 & .44 & & \\
\hline \multirow{3}{*}{$\begin{array}{l}\text { Adjust insulin according to capil- } \\
\text { lary blood glucose levels }\end{array}$} & $\mathrm{Md}$ & 3.00 & 3.00 & -2.854 & $.004 * *$ \\
\hline & $\bar{\chi}$ & 2.44 & 2.88 & & \\
\hline & $S D$ & .71 & .33 & & \\
\hline \multirow{3}{*}{ Participation in health services } & $\mathrm{Md}$ & 2.00 & 2.00 & -.492 & .623 \\
\hline & $\bar{\chi}$ & 1.84 & 1.90 & & \\
\hline & $S D$ & .70 & .58 & & \\
\hline \multirow{3}{*}{ Overall responsibility } & $\mathrm{Md}$ & 2.75 & 2.25 & -1.754 & .080 \\
\hline & $\bar{\chi}$ & 2.52 & 2.29 & & \\
\hline & $S D$ & .46 & .49 & & \\
\hline
\end{tabular}

** Significant $(p<.01)$

\section{Discussion}

During adolescence, the responsibility for diabetes self-care starts being transferred from the parents to the adolescents. Considering that parents assume the primary responsibility for managing diabetes during childhood, the adolescents assume increasing levels of responsibility (Anderson, Brackett, Finkelstein, \& Laffel, 1997 cited by Helgeson, Reynolds, Siminerio, Escobar, \& Becker, 2008). Thus, the concept of responsibility for self-care will be referred to as personal responsibility, which focuses on autonomy and accountability in the self-care roles inherent to diabetes management.

The adolescents' personal responsibility for selfcare care was assessed using a responsibility scale consisting of 15 items. The reliability of the scale was assessed through Cronbach's alpha coefficient for the total scale and for each dimension. For the total scale, the Cronbach's alpha coefficient was
.745, which indicates a good internal consistency. In relation to the dimensions of responsibility, the lowest value was found in the dimension of Health Maintenance (Cronbach's alpha of .545). After the internal consistency analysis, 12 of the 15 items of the scale remained as part of the four previously considered dimensions of responsibility: Health Maintenance; Disease Management; Diagnosis, Treatment and Medication in T1D; and Participation in Health Services. The remaining items were analyzed separately for not being consistent with the other items of the respective subscales: Control weight; Administer insulin; and Adjust insulin according to capillary blood glucose levels. The level of personal responsibility was assessed for the total scale, for each dimension and for the three items separately analyzed. Based on the results concerning the personal responsibility assumed in each dimension, we concluded that there is a virtually inexistent 
percentage of adolescents with low personal responsibility (0-1), which reveals a high personal responsibility for disease management. Overall, we found that the adolescents assume a personal responsibility for self-care roles, with most of them having a high level of personal responsibility $(\geq 2$ points on a scale of 0 to 3 points). These results contradict other studies whose results indicate that the control of blood glucose levels and decisionmaking are associated with the parents' knowledge about the disease but are not correlated with the adolescents' knowledge, in which responsibility is attributed to parents and adolescents are not autonomous in making decisions regarding diabetes (Wysocki et al, 2008). The data obtained show that mostadolescents have alreadya personal responsibility for self-care roles. However, the adolescents prove to have more personal responsibility for the item Administer Insulin (100\%), possibly because this is a more technical activity about which the adolescents receive instructions since their diagnosis and are imbued with a sense of responsibility since their short-term well-being depends on the correct performance of this technique. Despite this, there are several factors to be taken into account concerning responsibility. According to Dashiff, McCaleb, and Cull (2006), the interventions should differ according to the stage at which the disease is diagnosed. When the onset of diabetes occurs during childhood, the parents and health professionals' main concern should be on the performance of self-care roles. In turn, it occurs during adolescence, the intervention should focus more on the adolescents' accountability and development of a sense of autonomy. The transition to autonomy is complex and affected by several factors (Meleis et al., 2000, cited by Karlsson, Arman, \& Wikblad, 2008). Thus, it is important to consider individual factors that may facilitate or hinder the experience of diabetes in adolescence and to understand how each adolescent interprets, apprehends and builds their meanings about the disease, its therapeutic demands, and their adaptation to the social context.

The dimension in which adolescents clearly show the lowest personal responsibility is the Participation in Health Services, since only $70.6 \%$ reported a high level of personal responsibility and $29.4 \%$ reported that this is still a shared responsibility with their parents or other adults in this dimension. These results may be due to the fact that the adolescents' parents or legal guardians are the ones contacting the service and the professionals of reference, thus it is not a responsibility attributed to adolescents.

A further analysis was also conducted to verify the association between personal responsibility, gender and age. In relation to gender and overall responsibility, no significant correlation was found. However, a statistically significant difference was found in the item "Adjust insulin according to capillary blood glucose levels", since male adolescents have higher levels of personal responsibility. In a study on the impact of camps for diabetic adolescents to learn how to manage their disease, the authors concluded that the perception of autonomy varies according to gender, with girls showing lower levels of autonomy than boys in relation to group activities (Ramsing \& Hill, 2007). The same study also suggests that boys are more competitive among themselves and more autonomous in decision-making. In this way, the activities must be planned differently for boys and girls.

With regard to the association between personal responsibility for self-care roles and age, we found positive and statistically significant correlations between age and the dimensions Participation in Health Services and Diagnosis, Treatment and Medication in T1D and the item "Adjust insulin according to capillary blood glucose levels". Thus, older adolescents have higher levels of personal responsibility for the management of self-care roles. As regards the autonomy in self-care roles, Chien et al. (2007) consider that this variable depends on the age of adolescents with T1D. Thus, they are encouraged to administer insulin at to monitor blood glucose at 8 to 10 years of age, to administer insulin at 10 to 12 years of age, and to comply with meal plans at 12 to 14 years.

Throughout the study, some limitations emerged that influenced the results observed. We highlight the institutions' delay in authorizing the study. With regard to the number of participants, the sample size was considerably limited by the fact that most consultations were held every three months. 


\section{Conclusion}

T1D is a chronic disease with a significant impact on the life of adolescents and their families. With this study, it was possible to understand how diabetic adolescents manage the self-care roles concerning their personal responsibility for disease management. In this study, self-care management covers the strategies used by adolescents with T1D for metabolic control, establishing a balance between HbA1c, physical exercise, diet and insulin therapy. Thus, self-care management activities, namely the intake of carbohydrates, insulin administration and physical exercise, should be balanced for the maintenance of blood glucose levels. The results have repercussions for nursing care practice, especially in terms of the follow-up of diabetic adolescents and their families, intervening at the level of the adolescents' accountability for self-care. The results show that most adolescents assume personal responsibility for selfcare roles inherent to disease management. The level of maturity and cognitive development and gender issues are associated with the responsibility for selfcare roles in specific aspects. Gender does not seem to influence the adolescents' overall responsibility, with the exception for the item Adjust insulin according to capillary blood glucose levels, where there is a statistically significant difference since male adolescents show a higher personal responsibility. After the adaptation and assessment of its psychometric properties, the instrument, which was based on the model of self-care roles, proved to be a valid and reliable tool to assess responsibility for selfcare roles. Therefore, we believe that the instrument can be used with relative confidence; however, it still needs to be improved. We suggest the replication of studies in this area with the application of this instrument in other institutional contexts. The annual application of the questionnaire to adolescents being followed up in consultations would be a strategic way to assess the performance of diabetic adolescents in self-care management, allowing for the definition of problem-solving strategies adapted to each specific situation.

\section{References}

Aguiar, S., \& Fonte, C. (2007). Narrativas e significados da doença em crianças com diabetes mellitus tipo 1. Revista Psicologia, Saúde e Doenças, 8(1), 67-81.

Bastos, F., Severo, M., \& Lopes, C. (2007). Propriedades psicométricas da escala de autocuidado com a diabetes traduzida e adaptada. Acta Med Port., 20, 11-20.

Correia, L., Boavida, J. M., Almeida, J. P., Anselmo, J., Ayala, M.,Cardoso, S.,Costa, A.L...Rsposo,J. (2015). Diabetes: Factos e números 2014: Relatório anual do observatório nacional da diabetes. Retrieved from https://www.dgs. pt/estatisticas-de-saude/estatisticas-de-saude/publicacoes/ diabetes-factos-e-numeros-7-edicao.aspx.

Chien, S. C., Larson, E., Nakamura, N., \& Lin, S. J. (2007). Self-care problems of adolescents with Type 1 Diabetes in Southern Taiwan. Journal Of Pediatric Nursing, 22(5), 404-409.

Dashiff, C. J., McCaleb, A., \& Cull, V. (2006). Self-care of young adolescents. Journal of Pediatric Nursing, 21(3), 222-232.

Fialho, F. A., Dias, I. M., Nascimento, L., Motta, P. N., \& Pereira, S. G. (2011). Crianças e adolescentes com diabetes mellitus: Implicações para a enfermagem. Revista Baiana de Enfermagem, 25(2), 145-154.

Filho, C. V., Rodrigues, W. H. \& Santos, R. B. (2008). Papéis de autocuidado: Subsídios para a enfermagem diante das reações emocionais dos portadores de diabetes mellitus. Escola Anna Nery Revista de Enfermagem, 12(1), 125-129.

Garrett, S. P. (2007). Adesão ao tratamento da diabetes em adolescentes: Factores motivacionais (Masters dissertation). Universidade do Porto, Faculdade de Psicologia de Ciências da Educação. Porto, Portugal.

Hanna, K. M., \& Decker, C. L. (2010). A concept analysis: Assuming responsibility for self-care among adolescents with type 1 diabetes. Journal of Pediatric Surgical Nursing, 15(2), 99110.

Helgeson, V. S., Reynolds, K. A., Siminerio, L., Escobar, O., \& Becker D. (2008). Parent and adolescent distribution of responsibility for diabetes self-care: Links to health outcomes. Journal of Pediatric Psychology, 33(5), 497-508.

Karlsson, A., Arman, M., \& Wikblad, K. (2008). Teenagers with type 1 diabetes: A phenomenological study of the transition towards autonomy in self-management. International Journal of Nursing Studies, 45(4), 562-570.

Miculis, C. P., Mascarenhas, L. P., Boguszewski, M. C. , \& Campos, W. (2010). Atividade física na criança com diabetes tipo 1. Jornal de Pediatria, 86(4), 271-278.

Peixoto, M. R. (1996). Divergências e convergências entre um modelo de assistência de enfermagem a pacientes diabéticos e a teoria do déficit de autocuidado de Orem. Revista de Escola de Enfermagem São Paulo, 30(1), 1-13. Retrieved from http://www.scielo.br/pdf/reeusp/v30n1/v30n1a01.pdf 
Ramsing, R., \& Hill, E. (2007). How camps can help adolescents self-manage diabetes. Camping Magazine, 1-4.

Ribeiro, J. (1998). Psicologia e saúde. Lisboa, Portugal: ISPA.

Rosalind, B. (2006). A criança com disfunção endócrina. In M. J. Hockenberry, D. Wilson, Wong Fundamentos de enfermagem pediátrica (p.1063-1095). Rio de Janeiro, Brasil: Elsevier.

Santos, M. J., Silva, I., \& Cardoso, M. H. (2009). Avaliação da qualidade de vida e do controlo glicémico em diabéticos tipo
1 com bomba infusora de insulina. Revista Portuguesa de Endocrinologia, Diabetes e Metabolismo, 33-42.

Wysocki, T., Iannotti, R., Weissberg-Benchell, J., Laffel, L., Hood, K., Anderson, B., ... (2008). Diabetes Problem Solving by Youths with Type 1 Diabetes and their Caregivers: Measurement, Validation, and Longitudinal Associations with Glycemic Control. Journal of Pediatric Psychology, 33(8), 875-884. http://doi.org/10.1093/jpepsy/jsn024

World Health Organization (2011). Adolescent bealth. Geneva, Switzerland: Author. 
